Selected Papers from the 1st Latin American Radiocarbon Conference, Rio de Janeiro, 29 Jul.-2 Aug. 2019 (C) 2020 by the Arizona Board of Regents on behalf of the University of Arizona. This is an Open Access article, distributed under the terms of the Creative Commons Attribution-NonCommercial-NoDerivatives licence (http://creativecommons.org/licenses/by-nc-nd/4.0/), which permits non-commercial re-use, distribution, and reproduction in any medium, provided the original work is unaltered and is properly cited. The written permission of Cambridge University Press must be obtained for commercial re-use or in order to create a derivative work.

\title{
WHEN DID THE INCAS BUILD MACHU PICCHU AND ITS SATELLITE SITES? NEW APPROCHES BASED ON RADIOCARBON DATING
}

\author{
Mariusz Ziółkowski ${ }^{1 *}$ (D) Jose Bastante Abuhadba² Alan Hogg $^{3}$ (D) \\ Dominika Sieczkowska $^{1}$ (D) - Andrzej Rakowski ${ }^{4}$ (D) - Jacek Pawlyta ${ }^{4}$ (D) Sturt W Manning ${ }^{5}$ (D) \\ ${ }^{1}$ Centre for Andean Studies at Cusco, University of Warsaw, Poland \\ ${ }^{2}$ National Archaeological Park of Machu Picchu, Cusco, Peru \\ ${ }^{3}$ Waikato Radiocarbon Laboratory, University of Waikato, Hamilton, New Zealand \\ ${ }^{4}$ Division of Geochronology and Environmental Isotopes, Institute of Physics-CSE, Silesian University of Technology, \\ Gliwice, Poland \\ ${ }^{5}$ Cornell Tree Ring Laboratory, Cornell University, Ithaca, NY, USA
}

\begin{abstract}
According to the classical chronology of the Inca State, the ascension to power of Pachacuti Inca took place around AD 1438 and the construction of Machu Picchu began by AD 1450-1460. However, the improvement in the accuracy of radiocarbon $\left({ }^{14} \mathrm{C}\right)$ dating resulting from the application of Bayesian analysis has changed our view of the historical chronology. This new research raises questions about our understanding of the cultural development of the Machu Picchu area, in the light of the new proposed chronological scheme. This paper presents a set of 11 new ${ }^{14} \mathrm{C}$ dates, derived from AMS, from the sites of Llaqta of Machu Picchu, Chachabamba, and Choqesuysuy. The latter two sites are situated within the Machu Picchu National Archaeological Park (Arqueología del Santuario Histórico Nacional y Sitio Patrimonio Mundial de Machu Picchu) and have been interpreted as being part of the contemporary Late Horizon Inca landscape. The new ${ }^{14} \mathrm{C}$ ages are modeled using Bayesian inference and present a revised dating framework for these sites and their chronological relationship with Llaqta of Machu Picchu.
\end{abstract}

KEYWORDS: chronology, Inca Empire, Machu Picchu, radiocarbon AMS dating.

\section{INTRODUCTION}

At the time of its greatest expansion, by AD 1530, the Inca Empire, known as Tahuantinsuyu, stretched over a territory of more than one million square kilometers (Figure 1), with a population of (according to the most plausible modern estimates) 10-14 million inhabitants (Szemiński and Ziółkowski 2018).

The interpretation of the chronology and phases of expansion of the empire, rests on the so-called historical chronology proposed by John H. Rowe in 1945. According to this chronological scheme, based mainly on the Spanish chronicle of Miguel Cabello Balboa (dated 1586), the imperial phase of the Inca State began with the ascension to power, around AD 1438, of Pachacuti Inca Yupanqui, the ninth sovereign according to the so-called traditional list of Inca rulers. He and his successors, mainly Tupac Inca Yupanqui and Huayna Capac Inca, extended the State first to the NW of the capital city of Cusco to present-day Ecuador and then to the SE to the territories of what is now Bolivia, Argentina, and Chile. According to this model, the reign of these three rulers, calculated based on data taken from chronicles, lasted ca. 100 years (Rowe 1945).

An important element of the socio-territorial organization of the Inca empire comprised the so-called royal estates, private property of the sovereign. Machu Picchu and the areas

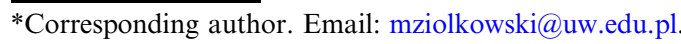




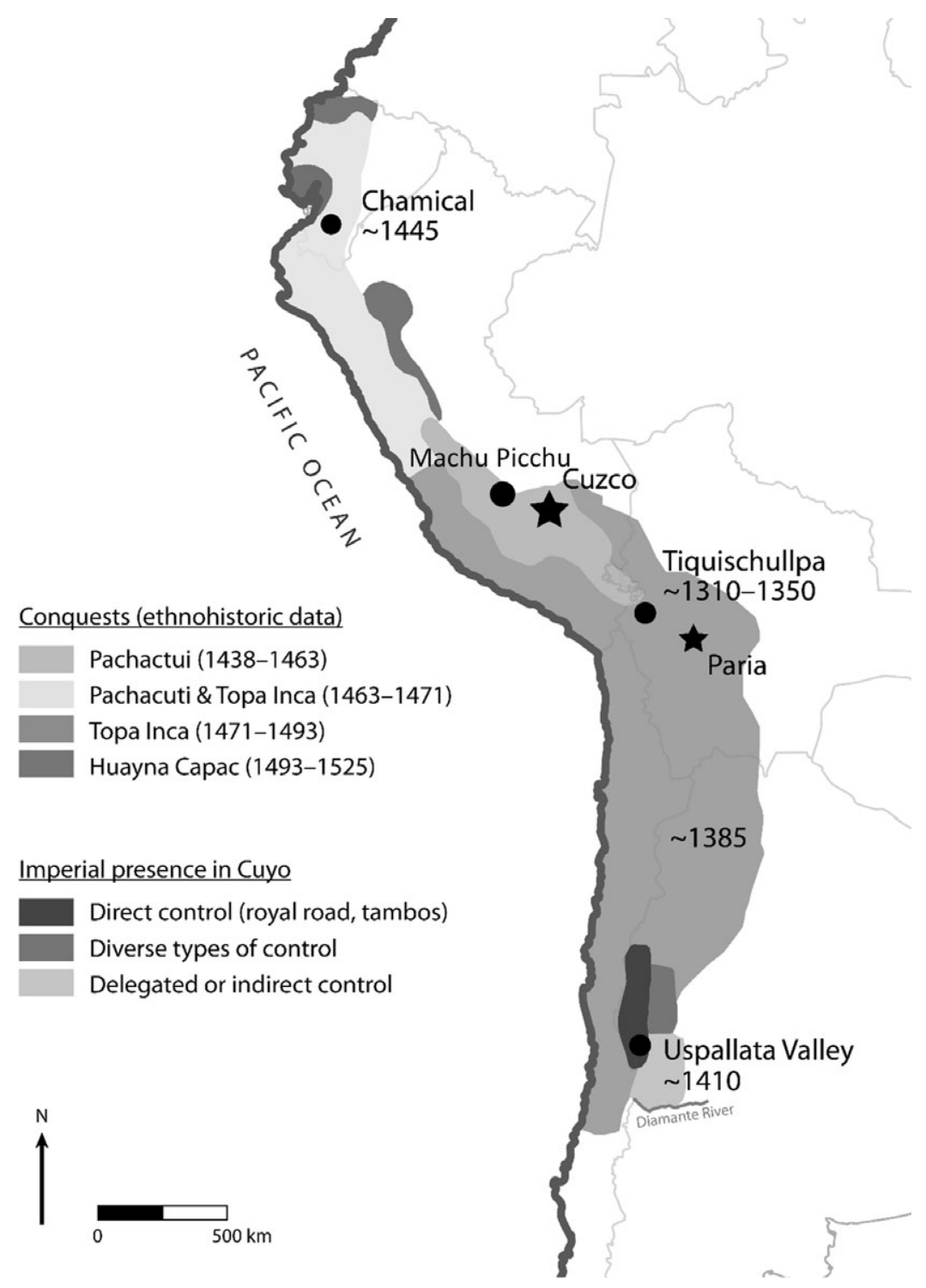

Figure 1 The Inca Empire reprint from Ogburn (2012: Figure 1).

surrounding this site constituted precisely one of these private holdings, attributed to Pachacuti Inca Yupanqui (Rowe 2003 [1986]). According to authors who base their opinions on historical sources, Pachacuti would have ordered the construction of the so-called Llaqta of Machu Picchu and a series of satellite sites by AD 1450 (Chavez Ballón 1971; Salazar 2004). This ceremonial and residential complex would have passed into the hands of the members of the Pachacuti clan (panaca), after the latter's death. This chronological scheme was, until recently, generally accepted by specialists and disseminated in the literature on the subject (Figure 1 and Table 1). 
Table 1 Historical chronology of the Inca Empire cf. John H. Rowe (Rowe 1945).

\begin{tabular}{ll}
\hline Year (AD) & Events \\
\hline 1438 & $\begin{array}{l}\text { Pachacuti deposes Viracocha, beginning of imperial conquest. } \\
\text { Pachacuti ruled } \\
1438-1471 \text { (33 years) } \\
\text { Pachacuti remains in Cuzco. Sons of Pachacuti including Topa Inca } \\
\text { lead the army on campaigns of expansion } \\
\text { Topa Inca succeeds Pachacuti } \\
1471-1493 \text { (22 years) } \\
1473\end{array} \begin{array}{l}\text { Chile conquered } \\
1493-1525 \text { (32 years) } \\
1525-1532 \text { (7 years) }\end{array} \begin{array}{l}\text { Huayna Copac ruled } \\
\text { contested by Atahuallpa } \\
\text { Pizarro captured Atahuallpa in Cajamarca }\end{array}$ \\
\hline
\end{tabular}

Critics of the Historical Chronology from Historical and Archaeological Points of View

Although the historical chronology is the most accepted version of events it does not mean there are no divergent models. Some authors have questioned the historical validity of the whole Inca dynastic list (Zuidema 1982), or, at least, the duration and chronological position of the reigns of the sovereigns in the list and the deeds that were attributed to them (Covey 2006; Ogburn 2012; Cornejo 2014). This position has been synthesized by Alan Covey:

"Archaeological data and comparative historical evidence indicate the traditional twelvegeneration king list cannot be treated as a complete plausible account of Inca succession and chronology [...] Pachacuti myth cannot explain the available evidence adequately, 1438 should not be used as a starting date for the Inca polity and history" (Covey 2006: 173-174).

For the purposes of this paper, however, of greater interest are studies concerning the absolute chronology of the development phases of the Inca State not based on historical sources but on natural science, mainly on radiocarbon $\left({ }^{14} \mathrm{C}\right)$ dating.

Unfortunately, the application of ${ }^{14} \mathrm{C}$ dating for the differentiation of the phases of formation and expansion of the Inca Empire has been relatively limited to date. This circumstance is the result of the preconceived notion that the imperial period of the existence of the Inca State was so short (a century or less) that the best, most precise ${ }^{14} \mathrm{C}$ dates available in the 1980 s or 1990s lacked the precision to contribute usefully to the temporal differentiation of the phases of its expansion. Other techniques, such as dendrochronology, were at that time practically irrelevant in the Andean region and only in recent years have these begun to gain some importance (Ghezzi and Ródriguez 2015).

However, even with these limitations, a 1996 study based on the composite probability distribution of calibrated ${ }^{14} \mathrm{C}$ dates relating to the pre-imperial and imperial phases of the expansion of the Inca Empire, offers some interesting and novel conclusions (Adamska and Michczyński 1996). This analysis indicated that, at $68 \%$ probability, the pre-imperial phase of the Inca State could be placed between AD 1280-1396, while the expansive or imperial phase would have occurred between AD 1401-1518. This study thus pointed to the expansion of the Inca state beginning several decades before the AD 1438 date commonly accepted as the starting point of the Imperial phase, derived from the historical chronology (Adamska and Michczyński 1996). 
An important step in the process of the rejection of the "historical chronology" was undoubtedly the work of Dennis Ogburn at the Inca site of Chamical in Ecuador. There, in an unquestionably Inca settlement, it was possible to differentiate a series of layers relating to different phases of the construction of Inca structures. Based on the Bayesian analysis of the sequence of ${ }^{14} \mathrm{C}$ dates, Ogburn formulated the following conclusion:

"Our chronology of Inca expansion can no longer be based on the historical accounts, and we should not be judging ${ }^{14} \mathrm{C}$ dates against the traditional chronology. Instead, we must base our chronology on ${ }^{14} \mathrm{C}$ dates, and evaluate the historical record in relation to them. $[\ldots]{ }^{14} \mathrm{C}$ dates will not provide the level of precision we might desire within the short span of the Inca empire. But they can still provide a level of accuracy that is not possible within the framework of the historical account of Inca provincial expansion [...] [W]e may be able to obtain dates of sufficient precision and accuracy to date the Inca incorporation of different provinces within a range of about 2 decades" (Ogburn 2012: 235).

Another very important step was the study by Marsh and collaborators of the Inca presence in Argentina. The Bayesian model based on $26{ }^{14} \mathrm{C}$ dates and $19 \mathrm{TL}$ dates allowed the authors of the study to formulate the following conclusions:

"The emerging archaeological chronology of the Inca expansion confirms that dates in documentary sources are incorrect and strongly supports the argument to build an Inca chronology with radiometric dates and Bayesian models. Contrary to the traditional sequence of conquests, the southern expansion began first. Inca forces arrived in northern Argentina and Chile in the final decades of the 14th century. They probably arrived at the southeastern edge of their empire in Mendoza at cal AD 1380-1430 (68\% probability). At this point, the empire stopped expanding southward and occupied the area for the next 100-190 yr (68\% probability). Conquering leaders then looked north and marched on Ecuador beginning cal AD 1430-1460 (68\% probability)." (Marsh et al. 2017: 20-21: Figure 1)

Similar results were obtained with the analysis of $59{ }^{14} \mathrm{C}$ and $155 \mathrm{TL}$ dates from different Inca sites in Chile. Apparently, the Inca occupation here occurred almost 100 years before 1470 AD, although differences between analyzed regions exist (Cornejo 2014).

\section{RADIOCARBON DATING OF MACHU PICCHU}

The chronology of the Machu Picchu region thus far has been based mainly on the model of Rowe (1945), more precisely, on this author's evaluation of the reign of Pachacuti Inca Yupanqui between AD 1438 and AD 1471. It has been estimated that the construction of llaqta of Machu Picchu would have been started about 10 years after the beginning of the reign of Pachacuti, that is around AD 1450 (Chavez Ballón 1971; Salazar 2004).

But what remains of this chronology, if now we are questioning the reliability of the time scale proposed by Rowe and in particular, the estimated dates of Pachacuti's rule?

A question arises: When (and on whose behalf) was Machu Picchu built?

In this context it will be necessary to consider not only the main site, the Llaqta of Machu Picchu itself, but also its 60 satellite sites; what was the chronological relationship between the latter and the principal site? 
Table 2 Machu Picchu: radiocarbon dates from the test pit excavated in 1983 (reprint from Berger et al. 1988).

\begin{tabular}{lccccl}
\hline UCLA no. & Level & Depth $(\mathrm{cm})$ & $\begin{array}{c}{ }^{14} \mathrm{C} \text { age } \\
(\mathrm{yr} \mathrm{BP})\end{array}$ & Calibrated age & Context \\
\hline $2538 \mathrm{~A}$ & 1 & $0-10$ & $595 \pm 105$ & AD 1250-1450 & - \\
$2538 \mathrm{~B}$ & 4 & $31-40$ & $2775 \pm 160$ & $800-1200 \mathrm{BC}$ & - \\
$2538 \mathrm{E}$ & 7 & $61-70$ & $380 \pm 40$ & AD 1450 & Floor I \\
$2538 \mathrm{~F}$ & 7 & $61-70$ & $390 \pm 40$ & AD 1450 & Floor I \\
$2538 \mathrm{~K}$ & 10 & $91-100$ & $2700 \pm 50$ & $900-1000 \mathrm{BC}$ & - \\
$2538 \mathrm{O}$ & 12 & $111-120$ & $1365 \pm 45$ & AD 650 & Floor II. Wall base \\
$2538 \mathrm{P}$ & 13 & $121-130$ & $2660 \pm 45$ & $800-1000 \mathrm{BC}$ & - \\
\hline
\end{tabular}

Machu Picchu has not been intensively investigated by ${ }^{14} \mathrm{C}$ dating; there are only $7{ }^{14} \mathrm{C}$ dates on samples from a test pit excavated in 1983, and 5 more from human bone collected by the Peruvian Yale Expedition in 1912 and 1915 (Berger et al. 1988; Ajie et al. 1992).

In regard of the latter (i.e. the human bone), the samples did not come from stratigraphic contexts, so they cannot be directly related to the deposits of the test pit excavated in 1983 . The samples were first dated using the collagen fraction by Berger et al. in 1988 and then by Ajie et al. in 1992, on the gelatin and osteocalcin fraction. Even taking the corrected values obtained in 1992, dates with uncertainties between 90 and 150 years do not allow any conclusions about the construction or abandonment phases of Llaqta of Machu Picchu.

The test pit excavated in 1983 and the dates obtained from the various levels assigned arbitrarily within it, according to Berger et al.: "indicate two distinct occupation levels recognizable so far at Machu Picchu: the last well-known during the Inca period (Lumbreras 1969) and an earlier one of the 7th century AD” (Berger et al. 1988: 709).

Comparison of the dates obtained from the different levels shows that these contexts represent in fact a rather disturbed stratigraphy. The two dates of floor I (Inca) context (level 7, UCLA $2538 \mathrm{E}$ and F) corresponding to AD 1450 are framed by dates of 800-1200 BC (UCLA 2538B) and 900-1000 BC (UCLA 2538K) obtained from levels 4 (above) and 10 (below), respectively (Table 2; Berger et al. 1988: 709; Bastante et al. 2017).

It is also necessary to emphasize, that the spatial and stratigraphic relationship between the excavations of 1983 and new work in 2017 by the Polish-Peruvian project reported here can only be established approximately, since there is no plan of the excavation of 1983, nor is a profile available with the precise location of the place where the samples were taken (compare Berger et al. 1988).

The distance between excavation units from 1983 and now 2017 is approximately $25 \mathrm{~m}$ in a straight line. Both locations are in the same living area called Sector V. It seems that the place where excavations were conducted in 1983 is basically at the same level as excavations in the Patio from 2017. However, these two excavations were conducted in different terraces.

Because of these problems of compatibility between the two excavations, we base our preliminary new study on a series of 11 recent ${ }^{14} \mathrm{C}$ dates from Llaqta of Machu Picchu and 


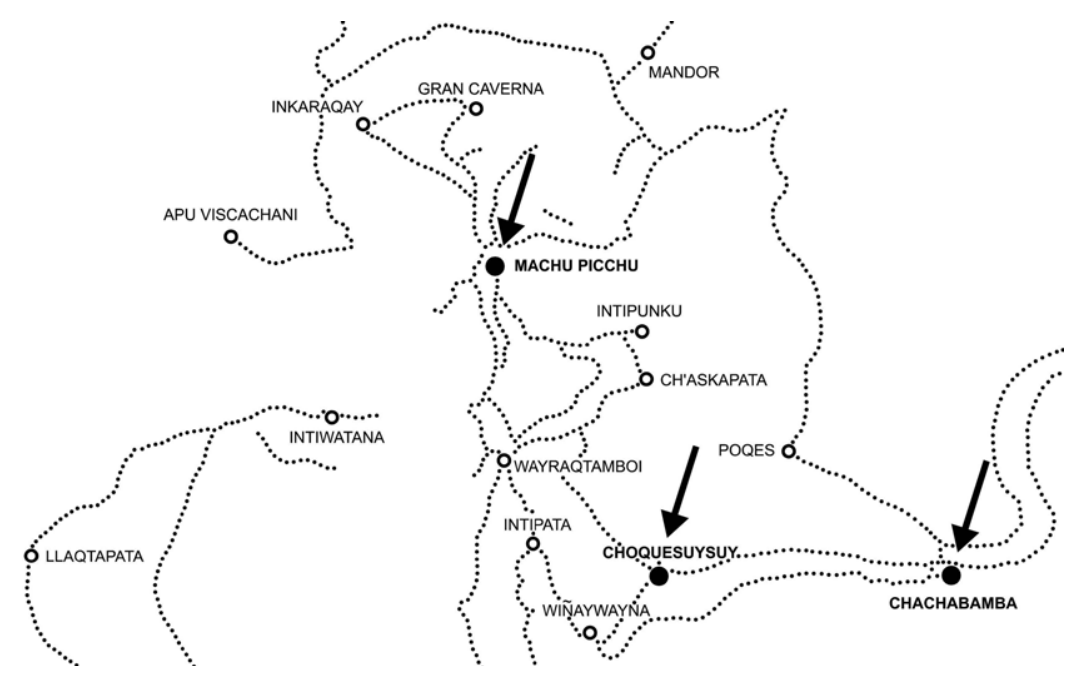

Figure 2 Location of Machu Picchu, Chachabamba, and Choqesuysuy (drawing by Jacek Kościuk).

2 satellite sites (Figure 2) carried out by the University of Waikato laboratory using $\mathrm{AMS}{ }^{14} \mathrm{C}$ dating. Sample numbers have been allocated employing the Waikato laboratory codes and come from the following locations:

1. Llaqta of Machu Picchu-3 samples;

2. Chachabamba-5 samples;

3. Choqesuysuy-3 samples.

The contexts from which the samples derive are detailed below. We state at the outset that the new data so far available are inadequate for a thorough chronology. They at best support the need for more work. We have very few dates, and especially lack dates on short-lived samples which might be regarded as contemporary with the relevant find contexts. We also lack replication for most contexts so far, limiting the ability to identify residual material. Unfortunately, the wood-charcoal samples offering typically TPQ estimates were not identified to species, nor considered in terms of characterization (whether heartwood, outer rings, roundwood, etc.) before dating. This limits our ability to comment on the likely scale of possible in-built age.

\section{The Llaqta of Machu Picchu Site and Sampling}

To begin, we will discuss the stratigraphy of the newly acquired samples based on date estimates resulting from the 2017 excavation data e.g. relative stratigraphic position, associated pottery, etc. (Figure 3). The first charcoal sample (Waikato 48116) came from excavation Unit 02-2017 (located on the so-called patio in the urbanized sector), layer III, interpreted as an Inca floor. The date obtained is associated with the construction phase of this Inca floor, and its period of use. Moreover, another sample of charcoal (Waikato 46935) came from layer IV situated below the Inca floor. It was found within the layer that predated the construction of the floor and related to the construction of the part of this sector, predating the Inca use of this space (Bastante et al. 2017). The last sample comes 


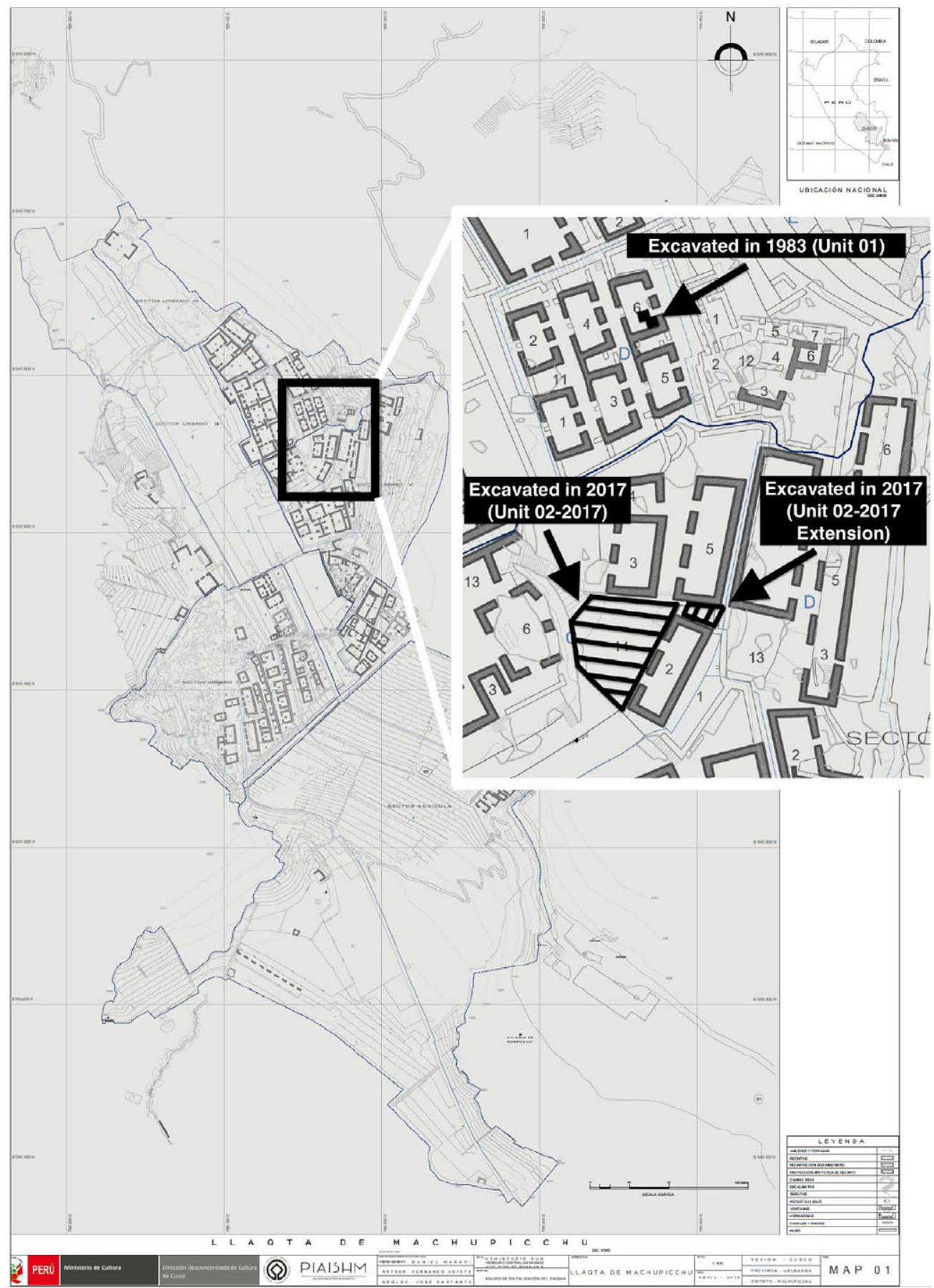

Figure 3 Relationship between samples from excavation in Llaqta of Machu Picchu in 1983 and 2017 (PIAISHM archives). 
from the neighboring nearby context to the patio area, from the extension to Unit 02-2017, and is related to the adjacent space. Here, within the second layer, a feature comprising a sacrificial context (number 01) was found. It was determined that it corresponded to the level of the Inca floor contemporary with the level of Inca occupation, which was rich in elements of charcoal (Waikato 46936). Due to the fact that the described unit is not uniquely related to $02-2017$, it is difficult to establish whether it is older or younger than the described samples. Nevertheless, it is certain that the sacrifice was made during Inca Times.

In our modeling analysis the two dates from level 7 of the test pit excavated in 1983, although related to an Inca Classic pottery sherds deposit (Berger et al. 1988), haven't been included because of the uncertain stratigraphy of this excavation (Valencia Zegarra and Gibaja Oviedo 1992).

\section{The Chachabamba Archaeological Site and Sampling}

Chachabamba is located on the left bank of the Vilcanota river at the 104th kilometer of the Cusco-Machupicchu Pueblo railway line. This site comprises a ceremonial complex related to the presence of its water-related shrine including 14 ceremonial baths. Excavations were conducted within the ceremonial sector of Chachabamba, designated sector A or 1. Most of the samples belong to the same excavation unit (03-2017). The most recent sample is part of layer III, while the oldest sample in this unit belongs to layer VIII. Within layer III, the level of Inca occupation was identified. Within this layer (i.e. III), it was possible to distinguish feature (01), which consisted of a ceramic arybalo type vessel comprising an offering including numerous pieces of charcoal. It is probable that they disintegrated under the weight of layer II. The Waikato 46938 sample pertains to this context. Just below (01), we found (03), consisting of a lens filled with charcoal and tiny branches (Waikato 48113). A further layer rich in charcoal in unit 03-2017 was layer VI (Waikato 46939). Finally, from within layer VIII, samples were taken associated with ceramics (Waikato 48114). The second excavation unit from which samples were taken was Unit 05-2017. A sample was included from layer VI, from the context of a circular wall located in the south-east corner of the excavation (Waikato 46940). Considering the direct level on which sample Waikato 46940 was deposited, which was higher than for sample Waikato 48114, it could be argued that the former is the oldest sample of those taken in Chachabamba.

\section{The Choqesuysuy Archaeological Site and Sampling}

Choqesuysuy is well known because of its multiple terraces but it is also important to mention its ceremonial and urban functions. It consisted of numerous residences and well-planned ceremonial structures as well as agricultural infrastructure. The ${ }^{14} \mathrm{C}$ samples from Choqesuysuy originate from two different excavation units from sector B (urban). The first sample came from the context of a collapsed wall which had fallen into the room in excavation Unit 01-2017. Sample Waikato 48115 was from the rubble derived from the postInca abandonment phase of use of the building. Layer IV of the same excavation unit corresponds to the level of Inca occupation. Furthermore, an additional charcoal sample was tested (Waikato 46933). The next sample came from excavation Unit 02-2017 in the same sector as Unit 01-2017. In layer II of Unit 02-2017, considerable amounts of charcoal were present (Waikato 46934), associated with numerous fragments of pottery (Bastante et al. 2017). 
Table 3 Results of radiocarbon dating of samples from Llaqta of Machu Picchu, Chachabamba, and Choqesuysuy, calibrated with OxCal 4.3.2 (Bronk Ramsey 1995, 2001). Mixed (50\%:50\% $\pm 10 \%)$ SHCal13 and IntCal13 curve was used for calibration. Unmodeled data.

\begin{tabular}{|c|c|c|c|c|}
\hline $\begin{array}{l}\text { Lab code } \\
\text { Waikato }\end{array}$ & Material & $\begin{array}{l}{ }^{14} \mathrm{C} \text { age } \\
\text { (BP) }\end{array}$ & Cal AD $1 \sigma$ & Cal AD $2 \sigma$ \\
\hline \multicolumn{5}{|l|}{ Machu Picchu } \\
\hline 48116 & Charcoal & $560 \pm 20$ & $1400-1421(68.2 \%)$ & $\begin{array}{l}1329-1338(3.7 \%) \\
1393-1432(91.7 \%)\end{array}$ \\
\hline 46935 & Charcoal & $490 \pm 18$ & $1430-1445(68.2 \%)$ & $1420-1450(95.4 \%)$ \\
\hline 46936 & Charcoal & $441 \pm 17$ & $1444-1460(68.2 \%)$ & $1439-1479(95.4 \%)$ \\
\hline \multicolumn{5}{|l|}{ Chachabamba } \\
\hline 48113 & Charcoal & $434 \pm 19$ & $1445-1468(68.2 \%)$ & $1440-1490(94.5 \%)$ \\
\hline 48114 & Charcoal & $475 \pm 19$ & $1434-1450(68.2 \%)$ & $1425-1455(95.4 \%)$ \\
\hline \multirow[t]{3}{*}{46938} & Charcoal & $338 \pm 18$ & $1514-1529(14.2 \%)$ & 1499-1600 (77.7\%) \\
\hline & & & $1539-1585(43.5 \%)$ & $1613-1640(17.7 \%)$ \\
\hline & & & $1620-1631(10.5 \%)$ & \\
\hline \multirow[t]{2}{*}{46939} & Charcoal & $391 \pm 15$ & $1463-1497(54.8 \%)$ & $1454-1510(68.4 \%)$ \\
\hline & & & $1602-1611(13.4 \%)$ & $1590-1619(27.0 \%)$ \\
\hline 46940 & Charcoal & $499 \pm 15$ & $1428-1441(68.2 \%)$ & $1420-1446(95.4 \%)$ \\
\hline \multicolumn{5}{|l|}{ Choqesuysuy } \\
\hline \multirow[t]{3}{*}{48115} & Charcoal & $209 \pm 20$ & $1666-1676(11.6 \%)$ & $1656-1684(20.9 \%)$ \\
\hline & & & $1740-1798(56.6 \%)$ & $1732-1804(71.6 \%)$ \\
\hline & & & & $1943-$ modern $(2.9 \%)$ \\
\hline \multirow[t]{2}{*}{46933} & Charcoal & $423 \pm 16$ & $1450-1472(68.2 \%)$ & $1445-1493(94.2 .5 \%)$ \\
\hline & & & & 1604-1607 (1.2\%) \\
\hline \multirow[t]{2}{*}{46934} & Charcoal & $567 \pm 16$ & $1440-1415(68.2 \%)$ & $1328-1340(5.2 \%)$ \\
\hline & & & & $1392-1425(90.2 \%)$ \\
\hline
\end{tabular}

\section{RESULTS}

The results of the dating of the 11 samples from Llaqta of Machu Picchu, Chachabamba, and Choqesuysuy are presented in Table 3. The calibrated ages were obtained using OxCal 4.3.2 (Bronk Ramsey 1995, 2001, 2009a). For calibration and modeling, the mixed SHCal13.14c and IntCal13.14c curves were used (Hogg et al. 2016; Marsh et al. 2018).

\section{Modeled Chronology for Llaqta of Machu Picchu, Chachabamba, and Choqesuysuy}

The sequence model was obtained using OxCal 4.3.2 (Bronk Ramsey 1995, 2009a) and is based on 11 dates from 3 Inca sites, Llaqta of Machu Picchu, Chachabamba, and Choqesuysuy. The two ${ }^{14} \mathrm{C}$ dates from Llaqta of Machu Picchu from excavations in 1983 (Berger et al. 1988) have not been included in the model because we are not convinced about their relation to the archaeological context of the samples from unit 02-2017. Because the sites are located around the edge of the ITCZ region, and especially since there are indications that in periods like the Little Ice Age partly contemporary with the Inca that the ITCZ boundary may have moved further south (e.g. Lechleitner et al. 2017), it is unclear whether to use the Southern Hemisphere (SH) or Northern Hemisphere (NH) or a mixed $\mathrm{SH}+\mathrm{NH}{ }^{14} \mathrm{C}$ calibration curve (see Hogg et al. 2016; Marsh et al. 2018). We tried to use different calibration curves to estimate consistent 
chronologies for those sites. We have tried to build models using IntCal13 and SHCal13 (Hogg et al. 2016) and mixed IntCal13+SHCal13, however the differences in chronologies for each of the calibration curves were negligible. For the modeling (Model 1), a mixed curve ( $50 \%: 50 \%)$ was used (Hogg et al. 2016). We have decided that a mixing approach is most appropriate for this region. Model 1 is based on the sequence inferred from the archaeological investigations. Each site is considered in a separate Sequence. A mixed curve of 50:50 $\pm 10 \%$ was employed. All dates are cal AD.

The results of the modeled chronology for Llaqta of Machu Picchu, Chachabamba, and Choqesuysuy are shown in the Figure 4. Most of the samples comprise carbonized wood, and thus offer terminus post quem (TPQ) information, except one which is a charred nut. All dated samples were included in the modeling. The OxCal General Outlier model (Bronk Ramsey 2009b) was applied to each element to assess the scale of outlier issues. Dates which could be too old (in-built age) are to be anticipated given wood charcoal samples and some potentially long-lived species (e.g. Cedrela angustifolia). We anticipated one particular problem. Assuming the stratigraphy is correctly recognized, it is evident that the sample used for Wk48116 must include either old wood (inner tree rings) or be residual material since it is clearly much older than the stratigraphically older context but more recent ${ }^{14} \mathrm{C}$ age of Wk46935 (and also Wk46936 as well as the two dates from Berger et al. (1988) from around the same horizon: UCLA 2538E, UCLA2528F). This sample returns the only contradictory (out of stratigraphic sequence) larger outlier probability $(\sim 23 \%)$. The other wood-charcoal dates, although likely involving varying amounts of in-built age, can work with the stratigraphic information. Chachabamba Layer III is the one other issue. Here within the same layer there is a marked difference in ages. Given just two samples and so no control, we can only assume that the more recent age offers the better (closer) TPQ and regard the older age as either inner tree-rings or residual material. The common initial dated event range across the three sites, gray bar in Figure 4, is 1391-1460 (95.4\% probability, 1401-1452 68.2\% probability).

The primary aim of this initial dating exercise is to determine the beginning date of Inca activity at each locus. We accept the dates on charcoal offer TPQ ranges. We thus placed an Outlier query against Wk48116 and Wk48113 in a revision of Model 1 (Model 2). We apply a First query to each site Phase as an estimate of the first dated TPQ event within the Phase. The results are shown in Figure 5. A mixed curve of 50:50 $\pm 10 \%$ was employed as in Figure 4. The probabilities for $\mathrm{Wk} 48116$ and $\mathrm{Wk} 48113$ lying in the Sequence are $0 \%$ and $1 \%$. There are inevitably loose upper and lower boundaries given the lack of data and constraints. The more restricted First estimates at an indicative $68.2 \%$ probability are Llaqta of Machu Picchu 1422-1448, Chachabamba 1412-1444, and Choqesuysuy 1354-1420. Date queries, the period between the start and end Boundaries for each site Phase (long in the case of Choqesuysuy with its post-Inca date), are also illustrated. Finally, even if very approximately, we might try to include an estimate of the TPQ involved. We can consider the Charcoal Plus Outlier model (Dee and Bronk Ramsey 2014) as perhaps the most appropriate for this data-poor and poorly constrained case. We employ all the data except Wk48116 (which prevents the model converging in most cases) with the Charcoal Plus Outlier model applied to the wood charcoal samples and the General outlier model applied to the nut (Model 3): Figure 6. This model assumed a 50:50 SH/NH mixed curve (and no error this time). The in-built age assumption of the Charcoal Plus Outlier model modifies (widens and especially extends) the First query assessments at $68.2 \%$ probability to: Llaqta of Machu Picchu 1421-1476, Chachabamba 1406-1480, and Choqesuysuy 1336-1470. 


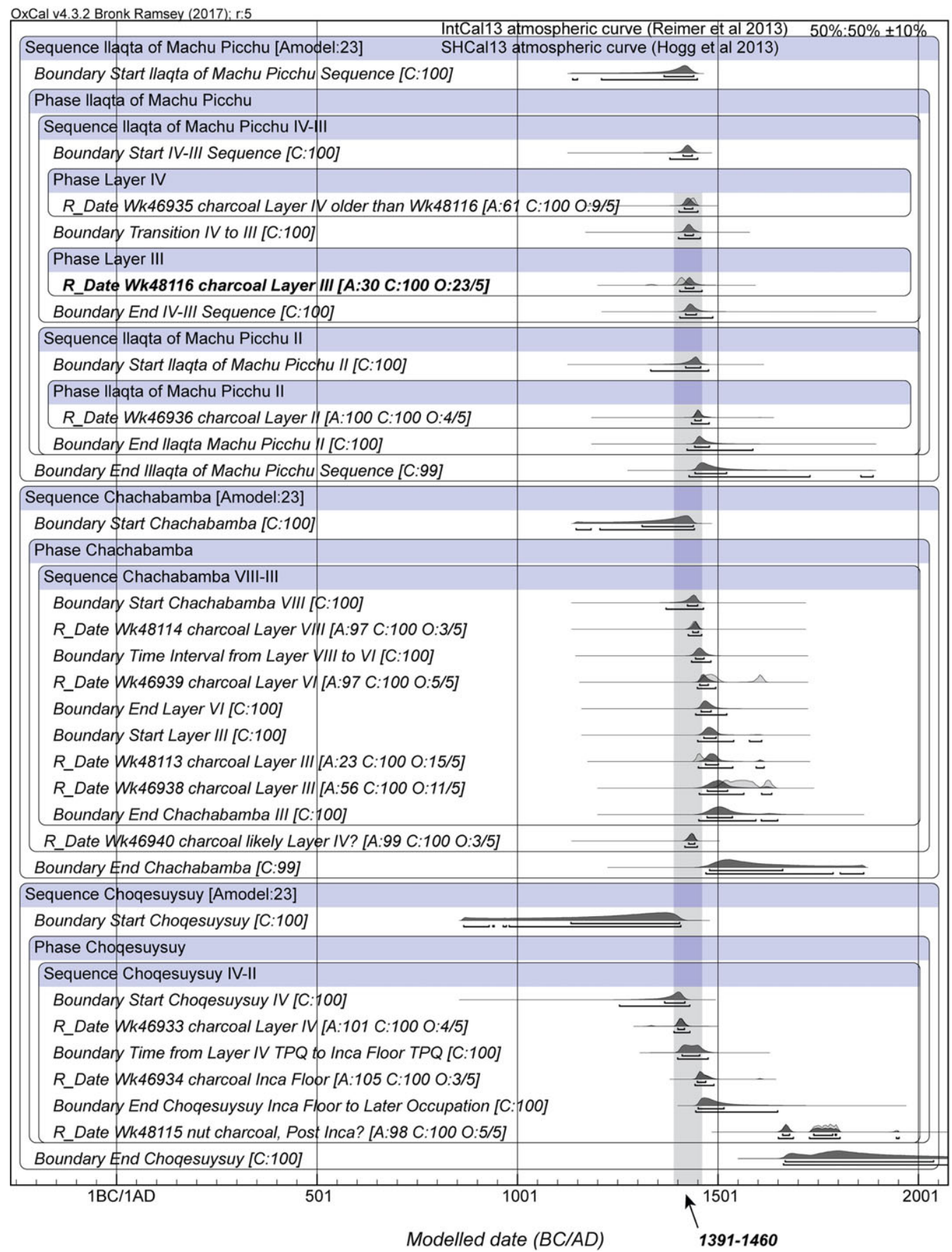

Figure 4 Modeled chronology for Llaqta of Machu Picchu, Chachabamba, and Choqesuysuy (Model 1) applying the OxCal General Outlier model. Mixed SHCal13 and IntCal13 curves (50:50 $\pm 10 \%)$ were used to build the model. The large out-of-sequence outlier Wk48116 is indicated in bold. Gray bar indicates the first dated sample range across all three sites. 


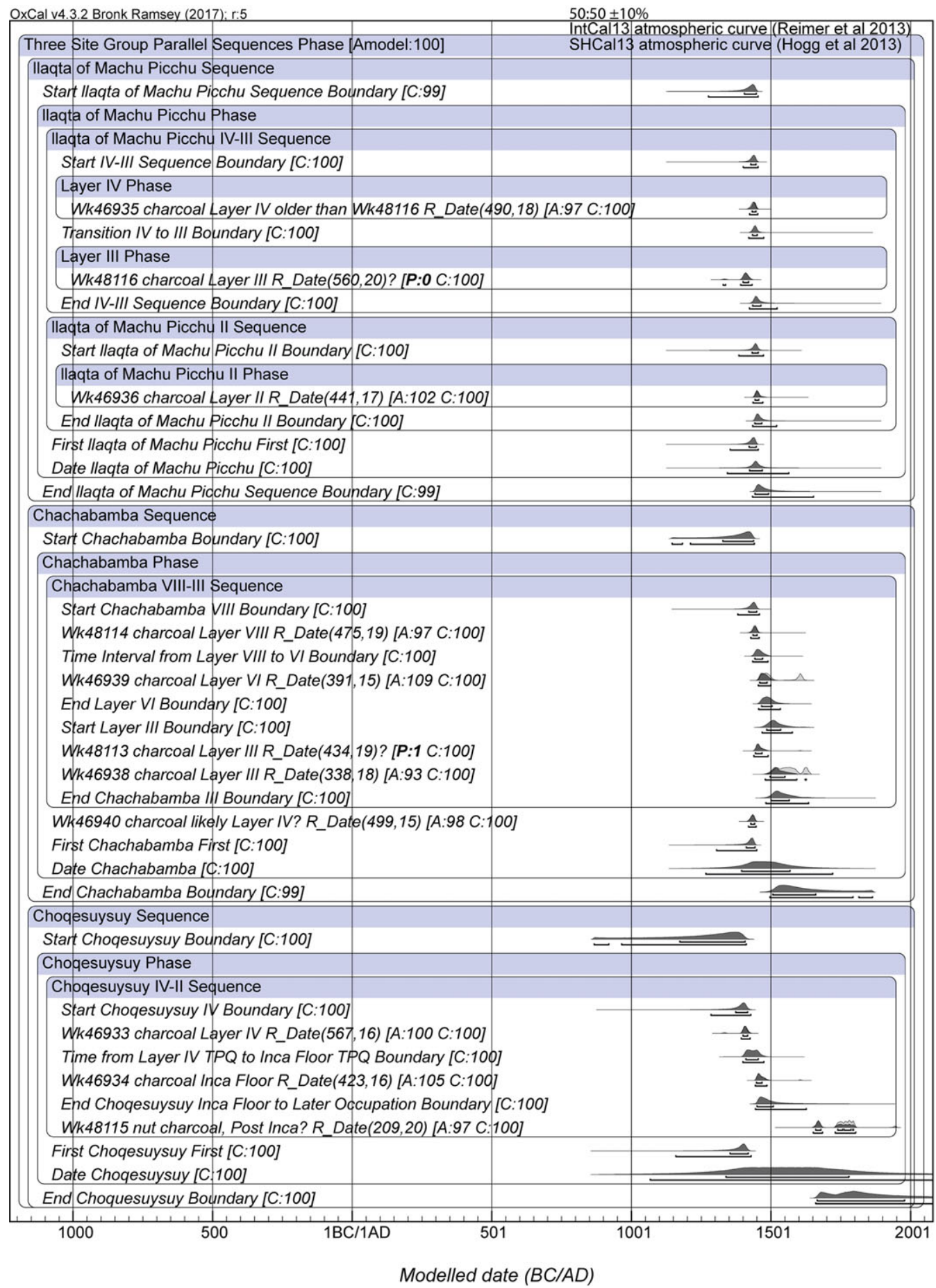

Figure 5 Model 2 chronology for Llaqta of Machu Picchu, Chachabamba, and Choqesuysuy applying Outlier queries against Wk48116 and Wk48113. Mixed SHCal13 and IntCal13 curves were used to build the model (50:50 $\pm 10 \%)$. First and Date queries are shown for each site Phase. 


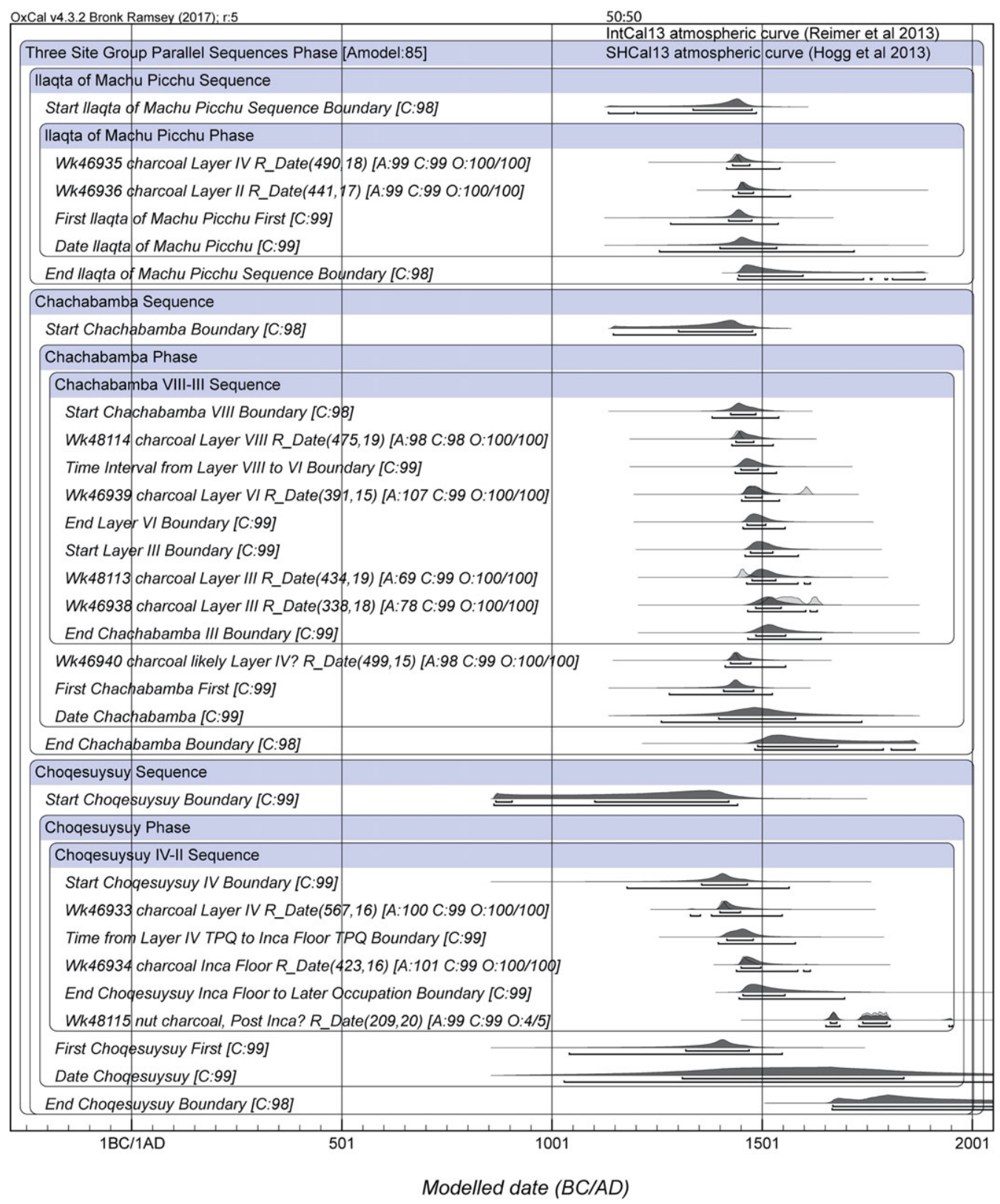

Figure 6 Model 3 chronology for Llaqta of Machu Picchu, Chachabamba, and Choqesuysuy applying the Charcoal Plus Outlier model (Dee and Bronk Ramsey 2014) against all the dates on wood charcoal to allow approximately for in-built age. The out-of-sequence outlier, Wk48116, has been excluded. The General Outlier model is applied to the nut sample (Wk48115). Mixed SHCal13 and IntCal13 curves were used to build the model (50:50 with no error). First and Date queries are shown for each site Phase.

Based on the results from Models 1 and 2, the initial phase for Llaqta of Machu Picchu and Chachabamba likely overlap (or are close in time), which may suggest that the construction of both sites commenced at the same time. For Choqesuysuy, Models 1 and 2 may suggest a possibility of a time span earlier than that obtained for Llaqta of Machu Picchu and 
Chachabamba. The attempt to allow approximately for the TPQ involved in all the dates relevant to the initial phases of the three sites (Model 3) could be consistent, but also allows that Choqesuysuy could in fact also be an early-mid 15th century construction. This limited data highlights the urgent need for a better chronology. Additional ${ }^{14} \mathrm{C}$ dates are necessary and especially on (i) annual or short lifespan organics associated with each phase at the site, and/or (ii) on wood charcoal samples using a wiggle-match or ordered sequence of dates to refine placement of outermost tree-rings (and hence human use or a best TPQ). Our results which involve the first use of Bayesian inference modeling of ${ }^{14} \mathrm{C}$ dates of sites in the Machu Picchu National Archaeological Park demonstrates the applicability of the methodology and the urgent need for further AMS dates on samples with known species identifications using Bayesian modeling.

\section{CONCLUSIONS}

The method based on Bayesian analysis described in this paper is the first attempt to use it to estimate the chronology of archaeological sites of Llaqta of Machu Picchu, Chachabamba, and Choqesuysuy. The proposed model suggests that Llaqta of Machu Picchu and Chachabamba were established around the same time period. On the other hand, the modeled chronology of Choqesuysuy suggests that it may have been built earlier than Llaqta of Machu Picchu and Chachabamba.

Because the investigated sites are in the area of the ITCZ, which may shift with even slight climatic changes, it will be necessary to investigate the impact of any such climatic events during periods of the sites' occupation. This would result in appropriate correction of the relevant Northern, Southern or mixed ${ }^{14} \mathrm{C}$ calibration curves.

This analysis was based on samples from three sites and for obvious reasons more comparative material from different contexts is needed. However, based on the results of the current research, corrections to the chronology of Machu Picchu region for the first half of the 15 th century are indicated.

Another important finding is that the Llaqta of Machu Picchu may have been preceded by other Inca installations in the area, specifically as indicated in our model by the site of Choqesuysuy.

This conclusion has additional support in the analysis of certain representations of rock art in the area that show that the site had a ceremonial importance several centuries before the occupation of this territory by the Incas (Astete et al. 2016, reinterpreted by Orefici 2017).

\section{ACKNOWLEDGMENTS}

This research was realized in the framework of the project: Function of the satellite archaeological sites in the vicinity of Machu Picchu: Inkaraqay and Chachabamba and the high mountain lakes on the foot of Nevado Salcantay (Peru) sponsored by a grant OPUS 2015/19/N/HS3/03557 from the National Science Centre of Poland.

We are also grateful to the Programa de Investigaciones Arqueológicas e Interdisciplinarias en el Santuario Histórico de Machu Picchu - Dirección Desconcentrada de Cultura de Cusco, for having made the samples available to the Project and having significantly supported the analysis of their archaeological context. 
Sample No:46940 from UE05 was excavated in the framework of the project: Armakuna: ritual functions of the Inca "baths" in the Chachabamba ceremonial complex (Historic Sanctuary of Machu Picchu, Peru) sponsored by a Grant Preludium 2015/19/N/HS3/03626 from the National Science Centre of Poland.

The research has been partly supported by Silesian University of Technology by grant 14/990/ BK_190119.

We are very grateful to Frank Meddens for the final revision and correction of this paper.

\section{REFERENCES}

Adamska A, Michczyński A. 1996. Towards radiocarbon chronology of the Inca State. ANDES, Boletin de la Misión Arqueológica Andina. Vol. 1. p. 35-60.

Ajie HO, Kaplan IR, Hauschka PV, Kirner D, Slota PJ Jr, Taylor RE. 1992. Radiocarbon dating of bone osteocalcin: Isolating and characterizing a noncollagen protein. Radiocarbon 34(3): 296-305.

Astete F, Bastante J, Echevarría López GT. 2016. Quilcas en el Santuario Histórico de Machupicchu-Parque Arqueológico Nacional de Machupicchu: análisis y perspectivas arqueológicas, Revista Haucaypata. p. 62-86

Bastante A, Astete F, Fernandez A. 2017. Informe Programa de Investigaciones Arqueológicas e Interdiciplinaras en el Santiario Histórico de Machupicchu, Informe Final de Excavaciones temporada de 2017 para casos de llaqta de Machupicchu, Chachabamba, Choquesuysuy; Ministerio de Cultura Cusco (manuscript).

Berger R, Chohfi R, Valencia Zegarra A, Yepez W, Fernandez Carrasco O. 1988. Radiocarbon dating Machu Picchu, Peru. Antiquity 62:707-710.

Bronk Ramsey C. 1995. Radiocarbon calibration and analysis of stratigraphy: the OxCal program. Radiocarbon 37(2):425-430.

Bronk Ramsey C. 2001. Development of the radiocarbon program OxCal. Radiocarbon 43(2A):355-363.

Bronk Ramsey C. 2009a. Bayesian analysis of radiocarbon dates. Radiocarbon 51(1):337-360.

Bronk Ramsey C. 2009b. Dealing with outliers and offsets in radiocarbon dating. Radiocarbon 51(3):1023-1045.

Cabello Balboa M. 1951 [1586]. Miscelánea antártica, una historia del Perú antiguo. L. E. Valcarcel, ed. Lima: Universidad Nacional Mayor de San Marcos, Instituto de Etnología

Chavez Ballón M. 1971. Cusco y Machu Picchu. Wayka, Revista del departamento de antropología de la Universidad del Cusco. Vol. 4-5. p. 1-4.

Cornejo L. 2014. Sobre la cronología del inicio de la imposición cuzqueña en Chile. Estudios Atacameños. Arqueología y Antropología Surandinas. No. 47. p. 101-116.

Covey RA. 2006. Chronology, succession, and sovereignty: the politics of Inca historiography and its modern interpretation. Comparative Studies in Society and History 48(1):169-199.

Dee M, Bronk Ramsey C. 2014. High-precision Bayesian modeling of samples susceptible to inbuilt age. Radiocarbon 56:83-94.

Ghezzi I, Rodríguez R. 2015. Primera serie dendroarqueológica en los Andes Centrales: resultados preliminares de Chankillo, Casma. Bulletin de l'Institut Français d'Études Andines, 44(1): 1-21.

Hogg A, Southon J, Turney C, Palmer J, Bronk Ramsey C, Fenwick P, Boswijk G, Boantgen U, Friedrich M, Helle G, Hughen K, Jones R, Kromer B, Noronha A, Reinig F, Reynard L, Staff R, Wacker L. 2016. Decadally resolved lateglacial radiocarbon evidence from New Zealand Kauri. Radiocarbon 58(4). doi: 10. 1017/RDC.2016.86.

Lechleitner FA, Breitenbach SFM, Rehfeld K, Ridley HE, Asmerom Y, Prufer KM, Marwan N, Goswami B, Kennett DJ, Aquino VV, Polyak V, Haug GH, Eglinton TI, Baldini JUL. 2017. Tropical rainfall over the last two millennia: evidence for a low-altitude hydrologic seesaw. Scientific Reports 7:45809.

Lumbreras L. 1969. Acerca del desarrollo cultural en los Andes. Mesa Redonda de Ciencias Prehistoricas y Antropologicas 2:125-154. Lima: P.U.C.

Marsh EJ, Kidd R, Ogburn D, Durán V. 2017. Dating the expansion of the Inca empire: Bayesian models from Ecuador and Argentina. Radiocarbon 59(1):1-24.

Marsh EJ, Bruno MC, Frits SC, Baker P, Capriles JM, Hastorf CA. 2018. IntCal, SHCal, or mixed curve? Choosing a ${ }^{14} \mathrm{C}$ calibration curve for archaeological and paleoenvironmental records from tropical South America. Radiocarbon 60(3):925-940. doi: 10.1017/RDC.2018.16.

Ogburn DE. 2012. Reconceiving the chronology of Inca Imperial expansion. Radiocarbon 54(2):219-237.

Orefici G. 2017. Informe de Arte Rupestre en el Parque Arqueológico Nacional de Machupicchu. Manuscrito Archivos del Centro de Estudios Andinos de la Universidad de Varsovia en el Cusco. 
Rowe JH. 1945. Absolute chronology in the Andean area. American Antiquity 10(3):265-284.

Rowe JH. 2003 [1986]. Machu Picchu a la luz de documentos del siglo XVI. In: Rowe JH, editor. Los Incas del Cuzco. Siglos XVI-XVII-XVIII. INC-Región Cusco. p. 117-126.

Salazar LC. 2004. Machu Picchu: mysterious royal estate in the cloud forest. In: Burger RL, Salazar LC, editors. Machu Picchu: unveiling the mystery of the Incas. Yale University Press. p. 21-48.
Szemiński J, Ziółkowski M. 2018. Mitos, rituales y política de los Incas. Arequipa: Ediciones El Lector.

Valencia Zegarra A, Gibaja Oviedo A. 1992. Machu Picchu: la investigación y conservación del monumento arqueológico después de Hiram Bingham, Municipalidad del Qosqo.

Zuidema T. 1982. Myth and history in ancient Peru. In: Rossi I, editor. The logic of culture. South Hadley (MA): Bergin and Garvey. p. 150-175. 